\title{
Trade Performance of Top 2 National Commodity Exchanges: MCX and NCDEX
}

\author{
K. Prabhakar Rajkumar, M. Thilaga
}

\begin{abstract}
The commodity futures trading is supported to all sectors of the economy, particularly farmers and consumers. Commodity producers optionally store some production for the future and go for futures contracts to hedge the uncertainty of the futures commodity price. Apart from that Indian commodity market requires major investment and commercial activities in the National and regional markets. But the demand and supply, Indian verses other currencies, export and import parity and current scenario news are the main factors are affecting the commodity trading. This study is focused the second boom period from 2011 to 2018 and identify the trade performances of number 1 and number 2 national commodity exchanges in India.
\end{abstract}

Keywords: Commodity Futures Market, Agriculture Commodity, Metals Commodity, Bullion Commodity, Energy Commodity.

JEL classification: G13, G14, G18, G20.

\section{INTRODUCTION}

The performances of commodity futures markets have a significant growth from 2003 onwards. Because, from 2000 onwards the Indian government took the decision to allow the national level online futures exchanges. Commodity futures market plays a vital role in build and rebuild to sustain and continue in India. During the pre independence period the commodity market was like furbelow. In 1952 due to war and natural calamities the essential commodities were pushed up in the shortage level. It resulted most of the commodities was banned to trade in the futures market.

According to Central Intelligence Agency (CAI) in 2017, the contribution of the agriculture sector to the GDP was 15.4 percent. The contribution of agriculture sector in India is higher than the world average level, that is 6.4, percent. When compared to the global agricultural output, India got 7.39 percent. When compared to equities, the commodities futures trading is getting more response. Because in India for agriculture and industrial sectors, the commodities are the essential inputs. Initial stage the regulatory system was in a critical position. Because spot trade is regulated by the Agriculture Product Market Committee (APMC) Acts. This act is used only for state level, and futures trade is regulated by the Union government. Initially the regulatory framework was undertaken by the Forward Market Commission (FMC) established in the year of 1953. But from 28th September 2015 onwards Security and Exchange Board of India (SEBI)

Revised Manuscript Received on October 25, 2019

Dr.K.Prabhakar Rajkumar, Associate Professor, Department of Commerce, Periyar University, Salem-11

M.Thilaga, Ph.D Research Scholar, Department of Commerce, Periyar University, Salem-11. was undertaken to regulate the commodity derivative market. Jignesh shah and financial technologies promoted National Spot Exchanges Limited (NSEC) suspended trading of all its contracts because of payments crises of over Rs. 5,600 crore. Hence the FMC was merged with SEBI.

\section{II.OBJECTIVES OF THE STUDY}

1. To identify the trade performance of Top two National Commodity Exchanges in India.

Many research articles have conducted on price volatility, price discovery and the relationship between spot and futures price, etc. But no one is doing the research on identifying the trade performance of No.1 and No.2 National Commodity Exchange in India. Hence, the researcher tries to fulfil the gap. This study mainly focuses on the trade performance of No. 1 and No. 2 commodity Exchanges in India by using the secondary data. For this purpose, yearly data were used from 2011 to 2018 in MCX and NCDX national exchange. These two exchanges all the commodities has divided into four categories, namely, Agriculture, Metals, Bullion and Energy.

\section{REVIEW OF LITERATURE}

Many researchers have conducted the research in many aspects on the Indian National commodity exchanges (Gulen and Mayhew 2000) was examined the impact of futures trading on cash price volatility before and after the introduction of futures trading. (Dineshkumar Sharma and meenakshi malhotra 2015) focused on the impact of futures trading on volatility of spot a cash of guar seed. For his study the data were taken from NCDEX. They found when the level of futures trading increases unexpectedly, the volatility of spot prices increases point toward the destabilizing impact of futures trading. (Tarun kumar soni 2014) to analyse the efficiency of futures market in Indian scenario he conducted the test of co-integration, linear and nonlinear causality on Indian agricultural futures contracts. He took four agriculture commodities, namely chena, wheat, soyabeen and mize from NCDEX. He found that three out of four futures contracts a long term relationship does exist. (Vishwanathan Iyar and Archna Pillai 2010) discuss the price discovery and convergence in the Indian Commodities market on six commodities from MCX. They found that the price discovery predominantly happening in the futures market and the convergence of information from futures in the spot market has been slow.

Published By:

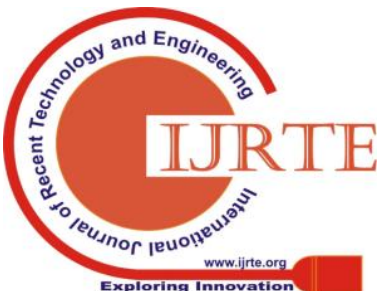


(Ragavendra, Velmufugan and Saravanan have examined the relationship of selected agricultural commodities in India: an efficiency causation analysis and the results show that there is one way casual linkage from futures market to spot market for soyabean and chana commodities. And the bidirectional relationship between futures and spot market for mize, jeera and turmeric commodities.

\section{ANALYSIS AND DISCUSSION}

\section{Trends in Commodity Derivatives at MCX}

The main purpose of the study is to identify the trade performance of No.1 and No.2 National Commodity Exchanges in India, which dealing Agriculture, Metal, Bullion and Energy commodities at MCX. The following tables and charts are clearly revealed about the trade performance of concern commodity derivatives at MCX from 2010-11 to 2018-19.

\section{Table-1. Trade Performance of Agri Commodity}

\begin{tabular}{|c|c|c|c|c|}
\hline \multirow[t]{2}{*}{ Period } & \multirow{2}{*}{$\begin{array}{l}\text { No.of } \\
\text { Trading } \\
\text { days }\end{array}$} & \multicolumn{3}{|c|}{ Agriculture } \\
\hline & & $\begin{array}{l}\text { Volume in } \\
\text { tonns } \\
(' 000)\end{array}$ & $\begin{array}{l}\text { Volume } \\
\text { (Lots) }\end{array}$ & $\begin{array}{l}\text { Turnove } \\
\text { ( crore) }\end{array}$ \\
\hline 2010-11 & 307 & 27,241 & $39,67,369$ & $1,14,152$ \\
\hline 2011-12 & 310 & 32,465 & $61,18,325$ & $1,97,781$ \\
\hline 2012-13 & 305 & 32,926 & $76,30,359$ & $2,70,295$ \\
\hline 2013-14 & 310 & 20,878 & $59,05,031$ & $1,71,391$ \\
\hline 2014-15 & 255 & 13,504 & $33,71,516$ & $1,10,268$ \\
\hline 2015-16 & 257 & 13,961 & $34,10,594$ & $1,21,699$ \\
\hline 2016-17 & 260 & 15,947 & $30,87,740$ & $1,39,312$ \\
\hline 2017-18 & 254 & 11,648 & $23,17,338$ & $1,14,082$ \\
\hline 2018-19 & 384 & 15673 & 3049133 & 157031 \\
\hline
\end{tabular}

Table-2 Trade Performance of Metals Commodity

\begin{tabular}{|c|c|c|c|c|}
\hline \multirow[t]{2}{*}{ Period } & \multirow{2}{*}{$\begin{array}{l}\text { No.of } \\
\text { Tradin } \\
\text { g days }\end{array}$} & \multicolumn{3}{|l|}{ Metals } \\
\hline & & $\begin{array}{l}\text { Volume in } \\
\text { tonns ('000) }\end{array}$ & $\begin{array}{l}\text { Volume } \\
\text { (Lots) }\end{array}$ & $\begin{array}{l}\text { Turnove } \\
\text { (crore) }\end{array}$ \\
\hline 2010-11 & 307 & $1,24,163$ & $7,41,49,730$ & $25,08,858$ \\
\hline 2011-12 & 310 & $1,18,499$ & $8,88,65,001$ & $27,09,758$ \\
\hline 2012-13 & 305 & $1,51,396$ & $11,39,43,114$ & $31,40,109$ \\
\hline 2013-14 & 310 & 85,674 & $6,37,97,242$ & $17,26,336$ \\
\hline 2014-15 & 255 & 62,083 & $4,73,52,037$ & $12,74,213$ \\
\hline $2015-16$ & 257 & 89,331 & $6,38,95,652$ & $15,05,004$ \\
\hline 2016-17 & 260 & 93,078 & $6,44,21,776$ & $17,53,887$ \\
\hline 2017-18 & 254 & 95,153 & $6,81,33,042$ & $21,12,532$ \\
\hline 2018-19 & 384 & 155649 & $1.1 \mathrm{E}+08$ & 3454905 \\
\hline
\end{tabular}

\section{Source: MCX}

Chart-1: Trend Focussed on Performance of Agri Commodity

Chart-1: Trend Focussed on Performance of Agri Commodity

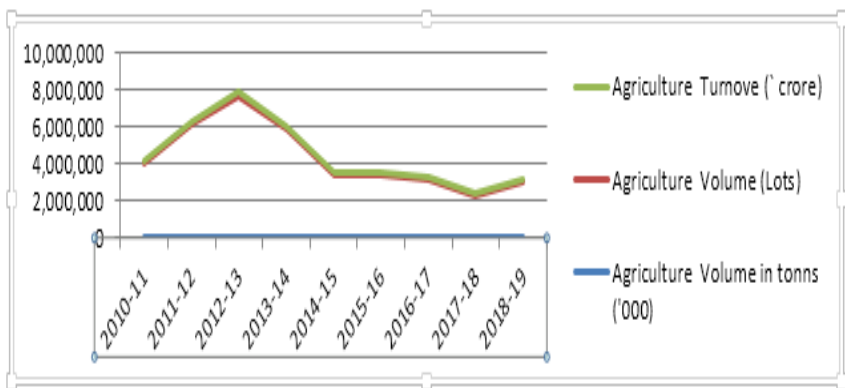

Chart-2: Trend Focussed on Performance of Metal Commodity

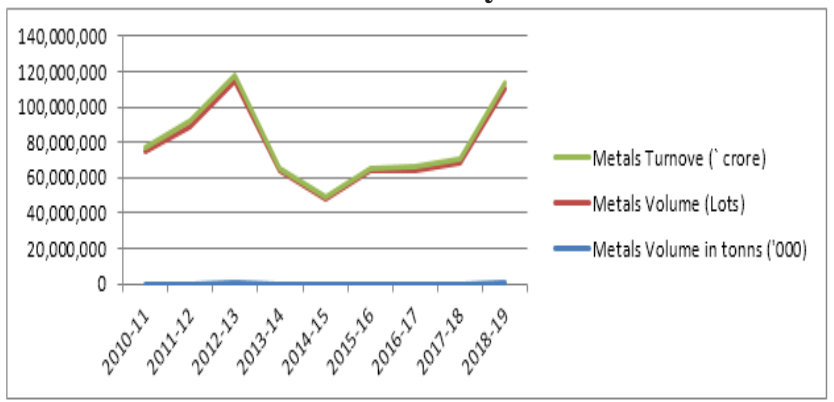

Table-3. Trade Performance of Bullion Commodity Table-4 Trade Performance of Energy Commodity

\begin{tabular}{|c|c|c|c|c|c|c|c|c|c|}
\hline \multirow[t]{2}{*}{ Period } & \multirow{2}{*}{$\begin{array}{l}\text { No,of } \\
\text { Tradi } \\
\text { ng } \\
\text { days }\end{array}$} & \multicolumn{3}{|l|}{ Bullion } & \multirow[t]{2}{*}{ Period } & \multirow{2}{*}{$\begin{array}{l}\text { Noof } \\
\text { Tradin } \\
\text { gdays }\end{array}$} & \multicolumn{3}{|l|}{ Energ' } \\
\hline & & \begin{tabular}{|l|} 
Volume \\
in tonss \\
(0OO)
\end{tabular} & $\begin{array}{l}\text { Volume } \\
\text { (Lots) }\end{array}$ & $\begin{array}{l}\text { Turnore } \\
\text { ( crovere) }\end{array}$ & & & $\begin{array}{l}\text { Volume in } \\
\text { tonns } \\
(000)\end{array}$ & Volume(Lots) & $\begin{array}{l}\text { Turnore } \\
\text { (croore) }\end{array}$ \\
\hline $2010 \cdot 11$ & 307 & 710 & $7,65,08,289$ & $51,69,268$ & 2010.11 & B07 & 631.869 & $5,81,72,478$ & $20,49,224$ \\
\hline $2011 \cdot 11$ & 310 & 1,011 & $22,83,4,4799$ & $99,63,667$ & 2011.11 & 310 & 730,401 & $6,652,26,548$ & 27,25889 \\
\hline $2012 \cdot 13$ & 305 & 723 & $16,22,79,284$ & $78,07,063$ & $0.12 \cdot 13$ & 305 & $8,16,377$ & $9,11,92,784$ & $36,63,589$ \\
\hline $2013 \cdot 14$ & 310 & 400 & $9,27,48,201$. & $42,63,195$ & 2013:14 & 310 & $4,21,354$ & $5,17,51,062$ & $24,00,52$ \\
\hline 2014.15 & 255 & 240 & $4,6294,585$ & $21,53,427$ & $2014+16$ & 255 & $4,04,556$ & $5,15,57,004$ & $16,45,799$ \\
\hline 2015.16 & 257 & 234 & 4,260282824 & $20,70,147$ & 2015.16 & 259 & $8,07,02$ & $12,43253,369$ & 19,373,34. \\
\hline 2016.17 & 260 & 207 & $3,1,51,500$ & $20,40,270$ & 2016-17 & 260 & $6,24,225$ & $11,78,49,477$ & $19,32.19$ \\
\hline $2017 \cdot 18$ & 254 & 164 & $278,40,060$ & $13,63,703$ & $2017 \cdot 18$ & 254 & $5,74,029$ & $10,76,34,52,2$ & $17,92,678$ \\
\hline .018 .19 & 384 & 255 & 42697200 & 2120931 & 2018.19 & 384 & 883010 & $17,03,49,4065$ & 3013808 \\
\hline
\end{tabular}

Chart-3 Trend Focussed on Performance of Bullion Commodity

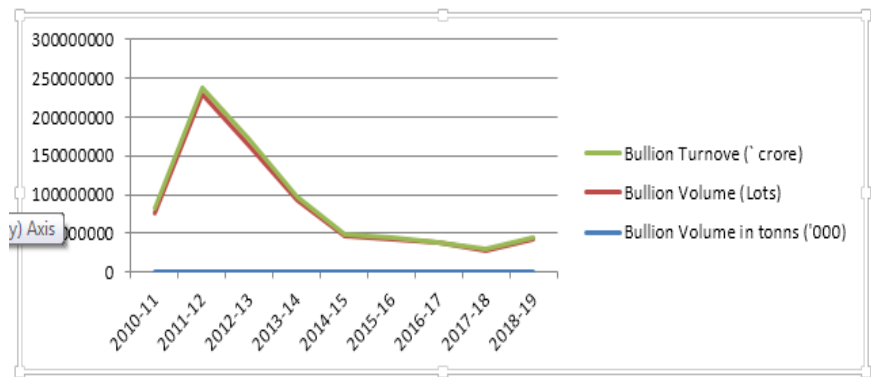

Chart-4. Trend Focussed on Performance of Energy Commodity

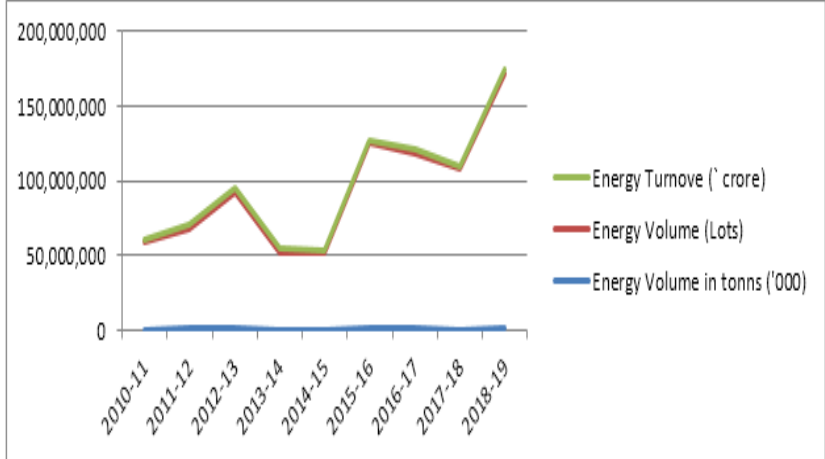


Table-5 Overall Trade Performances of all the Commodities

\begin{tabular}{|l|r|l|r|}
\hline \multirow{2}{*}{ Period } & \multicolumn{2}{|l|}{ Overall Total } \\
\cline { 2 - 4 } & $\begin{array}{l}\text { Volume } \\
\text { in tonns } \\
\text { ('000) }\end{array}$ & $\begin{array}{l}\text { Volume } \\
\text { (Lots) }\end{array}$ & $\begin{array}{l}\text { Turnove } \\
\text { ('crore) }\end{array}$ \\
\hline $\mathbf{2 0 1 0 - 1 1}$ & $7,83,984$ & $21,27,97,866$ & $98,41,502$ \\
\hline $\mathbf{2 0 1 1 - 1 2}$ & $8,82,377$ & $38,98,54,613$ & $1,55,97,095$ \\
\hline $\mathbf{2 0 1 2 - 1 3}$ & $10,01,423$ & $37,50,45,541$ & $1,48,81,057$ \\
\hline $\mathbf{2 0 1 3 - 1 4}$ & $5,28,306$ & $21,42,01,536$ & $86,11,449$ \\
\hline $\mathbf{2 0 1 4 - 1 5}$ & $4,80,383$ & $14,85,75,942$ & $51,83,707$ \\
\hline $\mathbf{2 0 1 5 - 1 6}$ & $9,11,229$ & $23,42,34,439$ & $56,34,194$ \\
\hline $\mathbf{2 0 1 6 - 1 7}$ & $7,83,457$ & $22,25,10,543$ & $58,65,661$ \\
\hline $\mathbf{2 0 1 7 - 1 8}$ & $6,80,995$ & $20,59,25,012$ & $53,82,996$ \\
\hline $\mathbf{2 0 1 8 - 1 9}$ & $10,54,588$ & $32,61,75,148$ & $87,46,674$ \\
\hline
\end{tabular}

Source: MCX

Notes: 1. Natural Gas volume are in mm BTU and is not included for computing for total volume and total open interest in '000 tonnes.

2. Conversion factors: Cotton (1 Bale $=170 \mathrm{~kg}$ ), Crude Oil (1 Tonne $=7.33$ Barrels)

\section{Chart-5 Trend Focussed on Overall Trade Performances} of all the Commodities

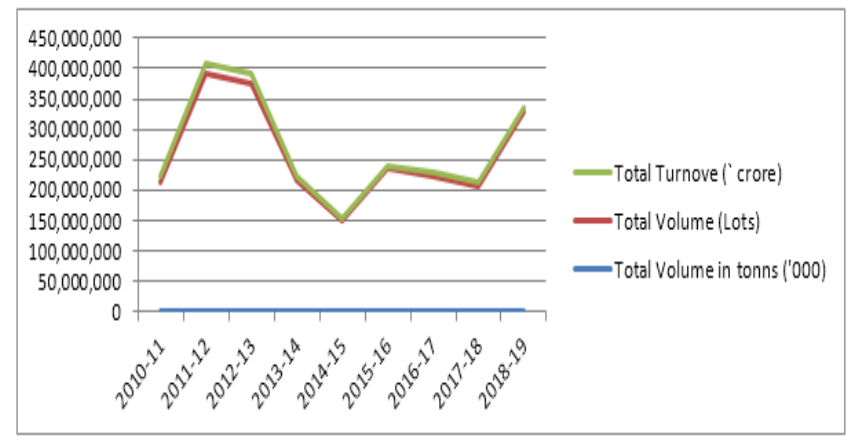

Here the researcher focused on Agriculture, Metals, Bullion and Energy commodities in MCX and NCDEX from 2010-11 to 2017-18. These four categories include all the commodities which are traded in these two exchanges. And for research purpose the number of trading days, volume (000 tonnes), volume (lots) and turnover in Rupees was taken. In MCX exchange all the four categories were getting the maximum trade volume and turnover, but in NCDEX exchange the agriculture category only got the maximum trade volume and turnover. When compared to the overall total trade volume and turnover MCX got 1st place and the NCDEX got 2nd place. When compared to four categories wise the MCX trade concentration is almost equal, but the

NCDEX maximum trade concentration is agriculture category only. So the NCDEX agriculture, trade contribution

is more than the MCX agriculture trade contribution.

If we taken the agriculture category in MCX exchange the year of 2012-13 the trade volume in tonnes was 32,926, the trade volume in lots was 79,30,359and the turnover was Rs.2,70,295 crore respectively. Likewise the metal category also got the highest trade volume in tonnes volume in lots and the turnover rupees in crore was 1,51,396 tonnes, 11,39,43,114 lots and Rs.31,40,109 crore. But in the bullion category in the year of 2011-12 got the highest value that is the volume in tonnes was 1,011 , the volume in lots was $22,83,44,739$ and the turnover was Rs. 99,63,667 crore. When compared to the energy category in the year of 2015-16 got the highest volume in tonnes was 8,07,702 volume in lots $12,43,25,369$ and the turnover was Rs 19,37,345 crore. But when we compared the overall total the highest trade volume in tonnes and volume in lots was in the year of 2012-13 $10,01,423$ and 37,50,45,541 respectively, and in the year of 2011-12 the turnover was Rs.1, 55,97,095 crore.

\section{Trends in Commodity Derivatives at NCDEX}

The main purpose of the study is to identify the trade performance of No.1 and No.2 National Commodity Exchanges in India, which dealing Agriculture, Metal, Bullion and Energy commodities at NCDEX. The following tables and charts are clearly revealed about the trade performance of concern commodity derivatives at NCDEX from 2010-11 to2018-19.

Table-6. Trade Performance of Agri Commodity

\begin{tabular}{|c|c|c|c|c|}
\hline \multirow[t]{2}{*}{ Period } & \multirow{2}{*}{$\begin{array}{l}\text { No.of } \\
\text { Tradin } \\
\text { g days }\end{array}$} & \multicolumn{3}{|c|}{ Agriculture } \\
\hline & & $\begin{array}{l}\text { Volume } \\
\text { in tonns } \\
\left({ }^{\prime} 000\right)\end{array}$ & $\begin{array}{l}\text { Volume } \\
\text { (Lots) }\end{array}$ & $\begin{array}{l}\text { Turnove } \\
\text { ( crore) }\end{array}$ \\
\hline $2010-11$ & 307 & $3,37,770$ & $3,96,10,809$ & $11,09,740$ \\
\hline $2011-12$ & 310 & $3.86,759$ & $4,41,73,798$ & $16,64,095$ \\
\hline 2012-13 & 304 & $3,47,242$ & $3,84,29,715$ & $15,57,146$ \\
\hline 2013-14 & 309 & $2,74,282$ & $3,36,46,539$ & $11,38,862$ \\
\hline 2014-15 & 255 & 1.94 .255 & $2,70,99,591$ & $8,70,863$ \\
\hline $2015-16$ & 257 & $2,17,736$ & $2,96,60,148$ & $9,98,811$ \\
\hline $2016-17$ & 260 & $1,28,790$ & $1,77,50,779$ & $5,96,530$ \\
\hline $2017-18$ & 248 & $1.33,172$ & 1.51 .87 .625 & $5,89,497$ \\
\hline 2018-19 & 373 & 191402 & 21983129 & 847266 \\
\hline
\end{tabular}

Source: NCDEX

Table-7 Trade Performance of Metals Commodity

\begin{tabular}{|c|r|r|r|}
\hline \multirow{2}{*}{ Period } & \multicolumn{3}{|l|}{ Metals } \\
\cline { 2 - 4 } & $\begin{array}{l}\text { Volume } \\
\text { in tonns } \\
\text { ('000) }\end{array}$ & $\begin{array}{l}\text { Volume } \\
\text { (Lots) }\end{array}$ & $\begin{array}{l}\text { Turnove } \\
\text { (crore) }\end{array}$ \\
\hline $\mathbf{2 0 1 0 - 1 1}$ & 8,998 & $12,05,418$ & 36,761 \\
\hline $\mathbf{2 0 1 1 - 1 2}$ & 4,182 & $8,31,959$ & 30,422 \\
\hline $\mathbf{2 0 1 2 - 1 3}$ & 782 & $2,08,002$ & 8,235 \\
\hline $\mathbf{2 0 1 3 - 1 4}$ & 3 & 1,349 & 58 \\
\hline $\mathbf{2 0 1 4 - 1 5}$ & 2 & 200 & 7 \\
\hline $\mathbf{2 0 1 5}-16$ & 0 & 0 & 0 \\
\hline $\mathbf{2 0 1 6 - 1 7}$ & 0 & 0 & 0 \\
\hline $\mathbf{2 0 1 7}-18$ & $\mathrm{Na}$ & $\mathrm{Na}$ & $\mathrm{Na}$ \\
\hline $\mathbf{2 0 1 8}-19$ & $\mathrm{Na}$ & $\mathrm{Na}$ & $\mathrm{Na}$ \\
\hline
\end{tabular}


Chart-6 Trend Focussed on Performance of Agri Commodity

Chart-6 Trend Focussed on Performance of Agri Commodity

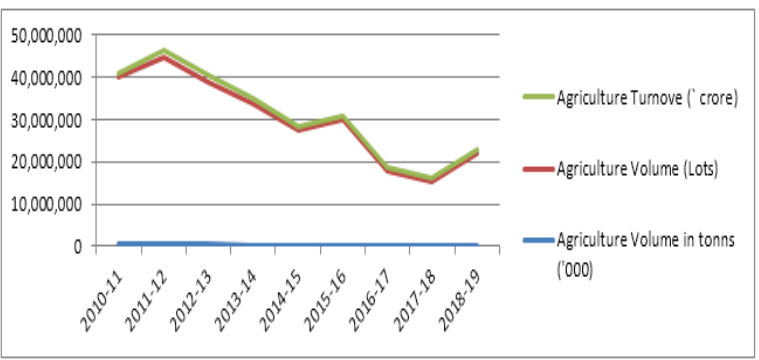

Chart-7 Trend Focussed on Performance of Metals Commodity

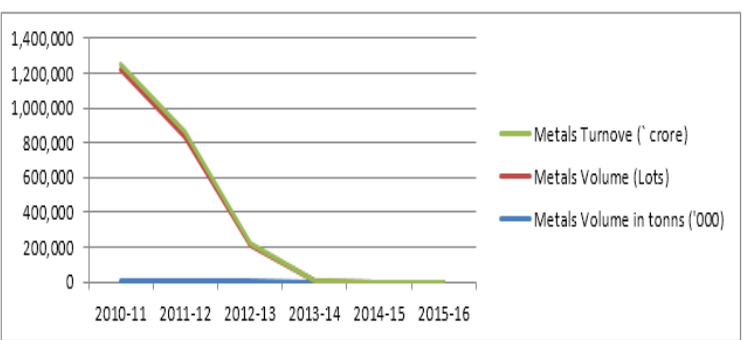

Table-8. Trade Performance of Bullion Commodity

\begin{tabular}{|c|c|c|c|c|}
\hline \multirow[t]{2}{*}{ Period } & \multirow{2}{*}{$\begin{array}{l}\text { No.of } \\
\text { Tradin } \\
\text { g days }\end{array}$} & \multicolumn{3}{|l|}{ Bullion } \\
\hline & & $\begin{array}{l}\text { Volume in } \\
\text { tonns } \\
(000)\end{array}$ & Volume (Lots) & $\begin{array}{l}\text { Turnove } \\
\text { ( crore) }\end{array}$ \\
\hline 2010-11 & 307 & 1.5 & $3,62,790$ & 70,928 \\
\hline 2011-12 & 310 & 2.3 & $1,43,742$ & 29,438 \\
\hline 2012-13 & 304 & 0.1 & 5,068 & 1,084 \\
\hline 2013-14 & 309 & 0.1 & 32,620 & 6,233 \\
\hline 2014-15 & 255 & 1.4 & $1,96,738$ & 32,708 \\
\hline 2015-16 & 257 & 0.6 & 94,494 & 20,778 \\
\hline $2016-17$ & 260 & 0.0 & 1,182 & 322 \\
\hline 2017-18 & 248 & $\mathrm{Na}$ & $\mathrm{Na}$ & $\mathrm{Na}$ \\
\hline 2018-19 & 373 & $\mathrm{Na}_{3}$ & $\mathrm{Na}_{3}$ & $\mathrm{Na}$ \\
\hline
\end{tabular}

\section{Source: NCDEX}

Table-9 Trade Performance of Energy Commodity

\begin{tabular}{|c|r|r|r|}
\hline \multirow{2}{*}{ Period } & \multicolumn{3}{|l|}{ Energy } \\
\cline { 2 - 4 } & $\begin{array}{l}\text { Volume in } \\
\text { tonns } \\
\text { ('000) }\end{array}$ & Volume (Lots) & $\begin{array}{l}\text { Turnove } \\
\text { (crore) }\end{array}$ \\
\hline $\mathbf{2 0 1 0 - 1 1}$ & 66,289 & $47,91,026$ & $1,93,173$ \\
\hline $\mathbf{2 0 1 1 - 1 2}$ & 26,651 & $19,47,870$ & 86,248 \\
\hline $\mathbf{2 0 1 2 - 1 3}$ & 8,594 & $6,29,902$ & 31,960 \\
\hline $\mathbf{2 0 1 3 - 1 4}$ & 257 & 18,862 & 1,175 \\
\hline $\mathbf{2 0 1 4 - 1 5}$ & 107 & 7,868 & 485 \\
\hline $\mathbf{2 0 1 5}-16$ & 0 & 0 & 0 \\
\hline $\mathbf{2 0 1 6 - 1 7}$ & 0 & 0 & $\mathrm{Na}$ \\
\hline $\mathbf{2 0 1 7 - 1 8}$ & $\mathrm{Na}$ & $\mathrm{Na}$ & $\mathrm{Na}$ \\
\hline $\mathbf{2 0 1 8 - 1 9}$ & $\mathrm{Na}$ & $\mathrm{Na}$ & \\
\hline
\end{tabular}

Chart-8 Trend Focussed on Performance of Bullion Commodity

Chart- 8 Trend Focussed on Performance of Bullion Commodity

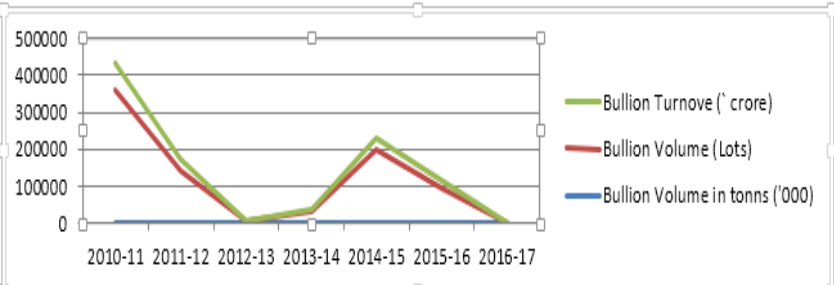

Table-10 Overall Trade Performances of all the Commodities

\begin{tabular}{|l|r|r|l|}
\hline \multirow{2}{*}{ Period } & \multicolumn{2}{|c|}{ Overall Total } \\
\cline { 2 - 4 } & $\begin{array}{l}\text { Volume in } \\
\text { tonns ('000) }\end{array}$ & Volume (Lots) & $\begin{array}{l}\text { Turnove } \\
\text { (crore) }\end{array}$ \\
\hline $\mathbf{2 0 1 0 - 1 1}$ & $4,13,058$ & $4,59,70,043$ & $14,10,602$ \\
\hline $\mathbf{2 0 1 1 - 1 2}$ & $4,17,594$ & $4,70,97,599$ & $18,10,204$ \\
\hline $\mathbf{2 0 1 2 - 1 3}$ & $3,56,617$ & $3,92,72,687$ & $15,98,426$ \\
\hline $\mathbf{2 0 1 3 - 1 4}$ & $2,74,544$ & $3,36,99,370$ & $11,46,328$ \\
\hline $\mathbf{2 0 1 4 - 1 5}$ & $1,94,365$ & $2,73,04,397$ & $9,04,063$ \\
\hline $\mathbf{2 0 1 5 - 1 6}$ & $2,17,737$ & $2,97,54,642$ & $10,19,588$ \\
\hline $\mathbf{2 0 1 6 - 1 7}$ & $1,28,790$ & $1,77,51,961$ & $5,96,852$ \\
\hline $\mathbf{2 0 1 7 - 1 8}$ & $1,33,172$ & $1,51,87,625$ & $5,89,497$ \\
\hline $\mathbf{2 0 1 8}-19$ & $1,91,402$ & $2,19,83,129$ & $8,47,266$ \\
\hline
\end{tabular}

Chart-10 Trend Focussed on Overall Trade Performances of all the Commodities

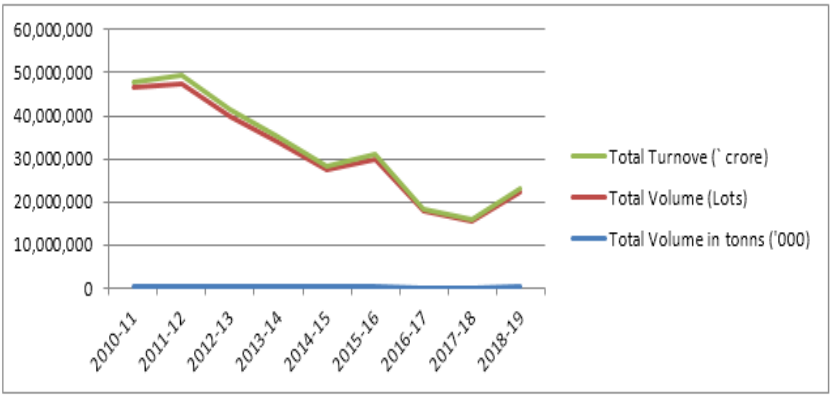

In NCDEX if we can take the agriculture category in the year of 2011-12 got the highest trade volume in tonnes 3,86,759, volume in lots was 4,41,73,798 and the turnover was Rs.16, 64,095 crore. When compared to the metal category in the year of 2010-11 got the highest trade volume 8,998 tonnes, $12,05,418$ lots and the turnover was Rs.36, 761 crore, but from 2015-16 onwards the trade contracts was observed zero. When we compared to bullion the high volume of tonnes 2.3 was observed in the year of 2011-12 and the volume of lots $3,62,790$, and the turnover Rs. 70,928 crore was observed in the year of 2010-11, but from 2017-18 onwards the bullion trade was observed in zero level. When compared to the energy category in the year of 2010-11 the value of tonnes was observed 66,289, the volume of lots was 47,91,026 and the turnover was observed Rs.1,93,173 crore. This category also was stopped to trade from 2015-16 onwards.

\section{V.CONCLUSION}

Commodity futures market plays a vital role in building and rebuilding to sustain and continue in India. According to CAI (Central Intelligence Agency) in 2017 the contribution of the agriculture sector to the GDP was 15.4 percent. The contribution of agriculture

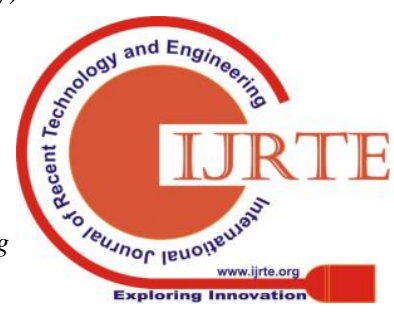


sector in India is higher than the world average level that is 6.4 percent. Initially the regulatory framework was undertaken by the Forward Market Commission (FMC) established in the year of 1953. But from 28th September 2015 onwards Security and Exchange Board of India (SEBI) was undertaken to regulate the commodity derivative market. India is the largest producer of agricultural commodities like rice, jeera, turmeric and wheat etc. Hence from 2003 onwards the Indian government allows the national level exchange to make online trading work. When compared to the overall total trade volume and turnover the MCX got 1st place and the NCDEX got 2nd place. When comparing to the agricultural trade category NCDEX has maximum of the trade contract than the MCX. The traders and marketing regulators support is more important to increase the trade performance of MCX and NCDEX.

\section{REFERENCES}

[1]. Raghaendra, velmurugan and saravanan(2016) Relationship Between Spot and Futures Markets of Selected Agricultural Commodities in India: An Efficiency and Causation Analysis, Journal of Business \& Financial Affairs, Vol-5, issue-1, ISSN: 2167-0234.

[2]. Thomas Dimpfl, Michael Flad, Robert C. Jung(2015), Price Discovery in Agricultural Commodity Markets in the Presence of Futures Speculation, Journal of Commodity Markets, vol-5, pp- 50-62.

[3]. Vishwanathan Iyer, Archana Pillai(2010), Price discovery and convergence in the Indian commodities market, Emerald Group Publishing Limited, Vol. 3 Issue:1, pp.53-61.

[4]. Dinesh Kumar Sharma, Meenakshi Malhotra(2015), Impact of futures trading on volatility of spot market-a case of guar seed, Vol. 75 No. 3, pp. 416-431.

[5]. Johannes Lubbers, Peter N.Posch(2016), Commodities Common Factor: An Empirical Assesment of the Market Deivers, Journal of Commodity Markets, No 4, pp. 28-40.

[6]. Tarun Kumar Soni(2014), Cointegration, Linear and Non-Linear Casualty Analysis Using Indian Agriculture Futures Contracts, Emerald Group Publishing Limited, Vol.4, No.2 pp.157-171.

[7]. Handbook of Statistics on Indian Securities Market 2018.

[8]. https://www.investopedia.com/terms/n/ncdex.asp Updated Apr 4, 2019, Reviewed by James Chen.

[9]. http://statisticstimes.com/economy/sectorwise-gdp-contribution-of-india. php

[10]. http://www.advisorymandi.com/blog/who-regulates-commodity-marketin-india/ 23-November-2018 9:28:38 AM

[11]. https://economictimes.indiatimes.com/markets/commodities/views/achhe -din-ahead-for-indias-agri-commodities-market-heres-how/articleshow/6 7403891.cms?from=mdr Jan 06, 2019, 11.12 AM IST.

[12]. https://economictimes.indiatimes.com/markets/commodities/news/basics -of-farm-futures/articleshow/68249665.cms?from=mdr 